\title{
Biovalorization of Brewery Waste by Applying Anaerobic Digestion
}

\author{
R. Vitanza, A. Cortesi," V. Gallo, I. Colussi, \\ and M. E. De Arana-Sarabia \\ Department of Engineering and Architecture, \\ University of Trieste, Piazzale Europa 1, \\ 34127 Trieste, Italy
}

doi: 10.15255/CABEQ.2015.2237

Original scientific paper

Received: June 4, 2015

Accepted: September 2, 2016

In the food industry, the brewing sector holds a strategic economic position: in the year 2013, the beer production of the EU-28 was equal to 383,553,000 hL. The brewing process includes chemical and biochemical reactions and solid-liquid separations, involving the generation of various residues and by-products, among which the major two fractions are brewer's spent grain (BSG), and exhausted brewery yeast (BY). Although until today their main use has been for animal feed, in recent years, several studies have investigated the application of anaerobic digestion in order to revalue the brewery wastes.

In this work, specific methane production (SMP) and first-order solubilisation (disintegration + hydrolysis) rates $\left(k_{\text {sol }}\right)$ for BSG and BY were evaluated. Biomethanation tests were performed in 5-L fed-batch stirred reactors at several substrate/inoculum ratios. The obtained SMP ranged from $0.255 \mathrm{~L} \mathrm{CH}_{4} \mathrm{~g}^{-1} \mathrm{COD}$ for exhausted brewery yeast to $0.284 \mathrm{~L} \mathrm{CH}_{4} \mathrm{~g}^{-1} \mathrm{COD}$ for brewer's spent grain. The estimated $k_{\text {sol }}$ values ranged from $0.224 \mathrm{~d}^{-1}$ for BSG to $0.659 \mathrm{~d}^{-1}$ for BY.

Key words:

anaerobic digestion, anaerobic biodegradability, brewery wastes, disintegration/hydrolysis, specific methane production, theoretical methane potential

\section{Introduction}

In the food industry, the brewing sector holds a strategic economic position: beer is the fifth most consumed beverage in the world, with an average consumption of $23 \mathrm{~L} /$ person/year $^{1}$. Based on the published statistics ${ }^{2}$, the EU-28 beer production in the year 2013 was equal to $383,553,000 \mathrm{hL}$, with Italian production of $13,256,000 \mathrm{hL}$.

The brewing process includes three chemical and biochemical reactions (mashing, boiling, fermentation/maturation), and three solid-liquid separations (wort separation, wort clarification, and rough beer clarification) $)^{1}$, involving the generation of various residues and by-products ${ }^{3}$. The originated organic waste materials consist of wastewater, spent grain, spent hops, hot break, yeast surplus, Kieselguhr and waste beer ${ }^{1,3-5}$. It is reported that the specific water consumption of a brewery ranges from 4 to 11 liters of water per liter of produced beer ${ }^{1}$.

Regarding the solid organic wastes, brewer's spent grain (BSG) is the main waste fraction of beer production, corresponding to around $85 \%$ of total generated by-products ${ }^{6,7}$ : In the EU, about 3.4 mil-

"Corresponding author. Tel: (0039) 040 5583755;

Fax: (0039) 040 569823; E-mail: angelo.cortesi@di3.units.it (Angelo Cortesi) lion tons of BSG are generated annually in beer production $^{8}$.

The brewer's spent grain is the by-product of the mashing process, one of the initial operations in brewing, and consists of a complex mixture of barley grain husk, pericarp, and fragments of endosperm $^{9,10}$.

Although its composition varies depending on the species of barley and brewing conditions, the BSG is predominantly a ligno-cellulosic material rich in protein and fiber 6 .

The second major by-product of the brewing industry is the Saccharomyces yeast biomass ${ }^{3}$. In the brewing process, yeasts are added to the wort to ferment them into alcohol. During alcoholic fermentation, the brewing yeast tends to multiply 3 to 5 times in the reactor ${ }^{5}$. Although it is common practice to reuse the brewery yeasts several times (from 4 to 6 ) to inoculate new fermentation tanks, large volumes of beer produced lead to the generation of significant amounts of waste ${ }^{3,5}$. Typically, the total amount of Saccharomyces yeast biomass produced in lager fermentation is about $0.17 \mathrm{~kg} \mathrm{hL}^{-1}-0.23$ $\mathrm{kg} \mathrm{hL}^{-1}$ of the final product ${ }^{3}$.

At present, the main use of brewer's spent grain and exhausted yeasts is for animal feed ${ }^{5}$.

In recent years, several studies have investigated the application of anaerobic digestion in order to 
revalue the brewery wastes ${ }^{11-14}$. Anaerobic digestion (AD) is used worldwide for the treatment of agro-industrial streams and sewage sludge from wastewater treatment plants, and contributes efficiently in solid waste reduction and biogas production ${ }^{15}$. The production and use of biogas generated by the AD process represents significant potential to achieve energy-related, environmental, and economic benefits ${ }^{16}$. However, the management of biogas plants is not trivial, and involves achievement of the correct organic loading rate (OLR), balance of the $\mathrm{C} / \mathrm{N}$ ratio, maintenance of the proper $\mathrm{pH}$ values, and mitigation of inhibitory effects ${ }^{17}$. Substrate characterization is a key task for designing and operating anaerobic digesters: The parameters of interest include moisture, volatile solids content, substrate structure, biodegradability and methane potential ${ }^{18-20}$. The substrate biodegradability via anaerobic digestion is usually determined by application of batch assays, generally known as Biochemical Methane Potential (BMP) tests ${ }^{16}$. Several batch methods for estimating the specific methane potential (SMP) of organic substrate are reported in literature, but without a standardized protocol ${ }^{21}$. Recently, García-Gen et al. $(2015)^{22}$ have compared the batch assays with consecutive batch feeds to the BMP test, concluding that the first ones facilitate the obtaining of an acclimated biomass to substrate under investigation avoiding any lag phase.

In this paper, the results of biomethanation tests performed with BSG and BY are reported. Complete characterization of the tested substrates was achieved by coupling the obtained laboratory parameters (total and volatile solids content, and COD) with the chemical composition data taken from literature. The measured SMP of each substrate was compared with the relating theoretical anaerobic biodegradability in order to check the effectiveness of AD. The obtained cumulative methane production curves were employed to estimate the first-order disintegration/hydrolysis rate constant.

\section{Materials and methods}

\section{Characterization of complex substrates}

Substrate composition is a major factor in determining the methane yield and methane production rates from the digestion of biomass ${ }^{20}$. It is well known, for example, that lignin, although an organic compound, is not anaerobically biodegradable ${ }^{18}$ and that appropriate $\mathrm{C} / \mathrm{N}$ ratios can favour the $\mathrm{AD}$ process $^{23}$.

The tested brewery wastes, collected from a local brewery (Friuli Venezia Giulia region), were characterized following two main steps: preliminary laboratory analysis, and chemical characterization. The laboratory analysis involved determination of the total and volatile solids ${ }^{24}$, as well as chemical oxygen demand ${ }^{25}$. The chemical characterization, aimed to calculate the methane potential, was accomplished using the composition data from Kanauchi et al. (2001) ${ }^{26}$ (for BSG), and Pacheco et al. $(1997)^{27}$ (for BY).

The chemical oxygen demand of each component (carbohydrates, proteins, lipids, and lignin) was calculated by the reaction of organic compound oxidation $^{28}$ :

$$
\begin{aligned}
& \mathrm{C}_{a} \mathrm{H}_{b} \mathrm{O}_{c} N_{d}+\left(a+\frac{b}{4}-\frac{c}{2}-\frac{3}{4} d\right) \mathrm{O}_{2} \rightarrow \\
& a \mathrm{CO}_{2}+\left(\frac{b}{2}-\frac{3}{2} d\right) \mathrm{H}_{2} \mathrm{O}+d \mathrm{NH}_{3}
\end{aligned}
$$

The theoretical methane production was obtained from the Buswell's equation ${ }^{29}$ :

$$
\begin{aligned}
& \mathrm{C}_{a} \mathrm{H}_{b} \mathrm{O}_{c}+\left(a-\frac{b}{4}-\frac{c}{2}\right) \mathrm{H}_{2} \mathrm{O} \rightarrow \\
& \left(\frac{a}{2}+\frac{b}{8}-\frac{c}{4}\right) \mathrm{CH}_{4}+\left(\frac{a}{2}-\frac{b}{8}+\frac{c}{4}\right) \mathrm{CO}_{2}
\end{aligned}
$$

that gives the theoretical methane potential related to volatile solids (eq. 3), and to COD (eq. 4):

$$
\begin{aligned}
B_{0, t h V S} & =\frac{\left(\frac{a}{2}+\frac{b}{8}-\frac{c}{4}\right) 22.4}{12 a+b+16 c}\left[S T P \frac{\mathrm{LCH}_{4}}{\mathrm{~g} V S}\right] \\
B_{0, \text { th } C O D} & =\frac{\left(\frac{a}{2}+\frac{b}{8}-\frac{c}{4}\right) 22.4}{\left(a+\frac{b}{4}-\frac{a}{2}\right) 32}\left[S T P \frac{\mathrm{LCH}_{4}}{\mathrm{~g} C O D}\right]
\end{aligned}
$$

where $22.4(\mathrm{~L})$ is the volume of $1 \mathrm{~mol}$ of gas at STP conditions, and $32\left(\mathrm{~g} \mathrm{~mol}^{-1}\right)$ is the $\mathrm{O}_{2}$ molar mass.

The anaerobic biodegradability of each substrate was calculated by dividing the theoretical SMP (related to COD) by the stoichiometric production of $0.350 \mathrm{~L} \mathrm{CH}_{4} \mathrm{~g}^{-1} \mathrm{COD}$ at STP conditions ${ }^{30}$.

Table 1, drawn from Angelidaki and Sanders (2004) $)^{18}$ and Koch et al. (2010) ${ }^{28}$, reports the theoretical oxygen demand and the value of $B_{0, \text { th }}$ of typical substrate components.

Table 2 summarizes the results of the characterizations. As may be seen, the theoretical methane potential of BSG was reported with both COD and VS units. The correlation between COD and VS was impossible to calculate for the BY substrate, because the brewery yeast slurry is rich in alcohols (mainly ethanol), derived from fermentation, which are likely to volatilize during solids determination. 
Table 1 - Theoretical oxygen demand (ThOD) and theoretical methane potential of typical substrate components

\begin{tabular}{l|c|c|c}
\hline Substrate & Composition & $\begin{array}{c}\text { ThOD } \\
{\left[\mathrm{g} \mathrm{OD} \mathrm{g}^{-1} \mathrm{VS}\right]}\end{array}$ & $\begin{array}{c}B_{\text {0th }} \\
{[\mathrm{STP} \mathrm{L}} \\
\left.\mathrm{CH}_{4} \mathrm{~g}^{-1} \mathrm{VS}\right]\end{array}$ \\
\hline Carbohydrate & $\left(\mathrm{C}_{6} \mathrm{H}_{10} \mathrm{O}_{5}\right) \mathrm{n}$ & 1.19 & 0.415 \\
Lignin & $\mathrm{C}_{10.92} \mathrm{H}_{14.24} \mathrm{O}_{5.76}$ & 1.56 & -- \\
Protein & $\mathrm{C}_{5} \mathrm{H}_{7} \mathrm{O}_{2} \mathrm{~N}$ & 1.42 & 0.496 \\
Lipid & $\mathrm{C}_{57} \mathrm{H}_{104} \mathrm{O}_{6}$ & 2.90 & 1.014 \\
\hline
\end{tabular}

Table 2 - Characteristics of tested substrates

\begin{tabular}{|c|c|c|}
\hline Parameter & BSG & BY \\
\hline $\mathrm{COD}^{(\mathrm{a})}\left[\mathrm{gCOD} \mathrm{g}^{-1} \mathrm{TS}\right]$ & 1.48 & 2.15 \\
\hline $\operatorname{TS}^{(\mathrm{a})}[\%]$ & 18.7 & 15.9 \\
\hline $\mathrm{VS}^{(\mathrm{a})}[\% \mathrm{TS}]$ & 97.5 & 92.3 \\
\hline Carbohydrates $^{(\mathrm{b})\left(^{*}\right)}[\% \mathrm{TS}]$ & 49.2 & 32.9 \\
\hline $\operatorname{Lignin}^{(b)}[\% \mathrm{TS}]$ & 12.3 & 0.0 \\
\hline Proteins $^{(b)}[\%$ TS $]$ & 25.0 & 56.0 \\
\hline Lipids $^{(\mathrm{b})}[\% \mathrm{TS}]$ & 11.0 & 3.4 \\
\hline $\operatorname{Ash}^{(a)}[\% \mathrm{TS}]$ & 2.5 & 8.3 \\
\hline $\mathrm{C} / \mathrm{N}^{(\mathrm{b}-\mathrm{c})}$ & 12.4 & 5.2 \\
\hline $\mathrm{COD} / \mathrm{N}$ & 36.3 & 14.3 \\
\hline $\begin{aligned} \mathrm{B}_{0 \mathrm{th}}^{(\mathrm{b}-\mathrm{c})} & {\left[\mathrm{STP} \mathrm{L} \mathrm{L}_{\mathrm{CH}_{4}} \mathrm{~g}^{-1} \mathrm{VS}\right] } \\
& {\left[\mathrm{STP} \mathrm{L} \mathrm{CH}_{4} \mathrm{~g}^{-1} \mathrm{COD}\right] }\end{aligned}$ & $\begin{array}{l}0.408 \\
0.304\end{array}$ & $\begin{array}{c}- \\
0.350\end{array}$ \\
\hline Anaerobic biodegradability ${ }^{(\mathrm{c})}[\%]$ & 86.9 & 100 \\
\hline
\end{tabular}

(a) from analysis, (b) from literature, (c) calculated $(*)$ without lignin

For this kind of waste, containing a significant proportion of highly volatile compounds, the organic content is represented more accurately by $\mathrm{COD}^{19}$.

\section{Inoculum}

The employed inoculum was collected at a WWTP anaerobic digester, operating the co-digestion of waste sludge and organic fraction of municipal solid waste (OFMSW). The anaerobic sludge was analyzed in order to determine the total and volatile solids content, according to Standards Methods $^{24}$, and the total COD, measured according the method developed by Raposo et al. $(2008)^{25}$. Soluble COD and ammonia nitrogen were measured by Hach-Lange test cuvettes.

Before starting the biomethanation tests, the anaerobic sludge was pre-incubated for 15 days in order to deplete the residual biodegradable organic material ${ }^{21}$. The biogas produced during this period was collected, and its composition was analyzed obtaining the endogenous (i.e. with no external feed) specific methanogenic activity $\left(\mathrm{SMA}_{\text {end }}\right)$ of the inoculum. After this degassing period, the sludge sample was diluted (almost 1.5 times) and fed into the reactors to carry out the tests. The characteristics of the sludge at the beginning of the tests are reported in Table 3.

\section{Experimental set-up}

The biomethanation tests were carried out in homemade equipment shown in Figure 1 at mesophilic conditions. The anaerobic reactors were glass bottles, with $5 \mathrm{~L}$ of volume each, placed in a controlled temperature environment (water bath with a Julabo MB heating immersion circulator) at $35{ }^{\circ} \mathrm{C}$ $\left( \pm 0.1^{\circ} \mathrm{C}\right)$, and mixed continuously with magnetic stirrers (ARE, Velp Scientific) to suspend the sludge solids. Pressure transducers (RS Instrument) were connected to the bioreactors to outline the pressure changes during the test. A volumetric method with water displacement ${ }^{31}$ was used to measure the biogas produced, and its composition was determined using a gas analyzer (GA 2000 plus, Geotechnical Instruments). All the data were recorded by a PC.

The biomethanation tests for BSG and BY were performed simultaneously in two separate reactors. The overall duration of the experiment was 50 days, during which period the reactors were fed six times (each). For a given substrate, after the feed, the production of biogas was monitored and recorded for 6-12 days up to reaching the minimum biogas flow of $0.15 \mathrm{~mL} \mathrm{~min}{ }^{-1}$, value set as the proper limit for the production recording of the equipment. This consecutive batch test approach was followed according to Garcia-Gen et al. (2015) ${ }^{22}$ in order to facilitate the biomass acclimatization to the substrate under investigation.

The applied substrate to inoculum ratios (S/I) varied from $3 \%$ to $8 \%$ in COD basis. These low values were selected to reduce the reaction times ${ }^{22,32}$ allowing to maintain a biomass with good activity ${ }^{22}$.

Table 3 -Inoculum characteristics

\begin{tabular}{|c|c|}
\hline Parameter & \\
\hline Total Solids $\left[\mathrm{gTS} \mathrm{L}^{-1}\right]$ & 15.89 \\
\hline Volatile Solids $\left[\mathrm{gVS} \mathrm{L}^{-1}\right]$ & 9.25 \\
\hline $\mathrm{tCOD}\left[\mathrm{gCOD} \mathrm{L}^{-1}\right]$ & 14.32 \\
\hline $\mathrm{sCOD}\left[\mathrm{mgCOD} \mathrm{L}{ }^{-1}\right]$ & 1553 \\
\hline $\mathrm{N}-\mathrm{NH}_{4}\left[\mathrm{mg} \mathrm{N} \mathrm{L}^{-1}\right]$ & 513 \\
\hline $\mathrm{SMA}_{\text {end }}\left[\mathrm{gCOD}-\mathrm{CH}_{4} \mathrm{~g}^{-1} \mathrm{VS} \mathrm{d}^{-1}\right]$ & 0.046 \\
\hline
\end{tabular}




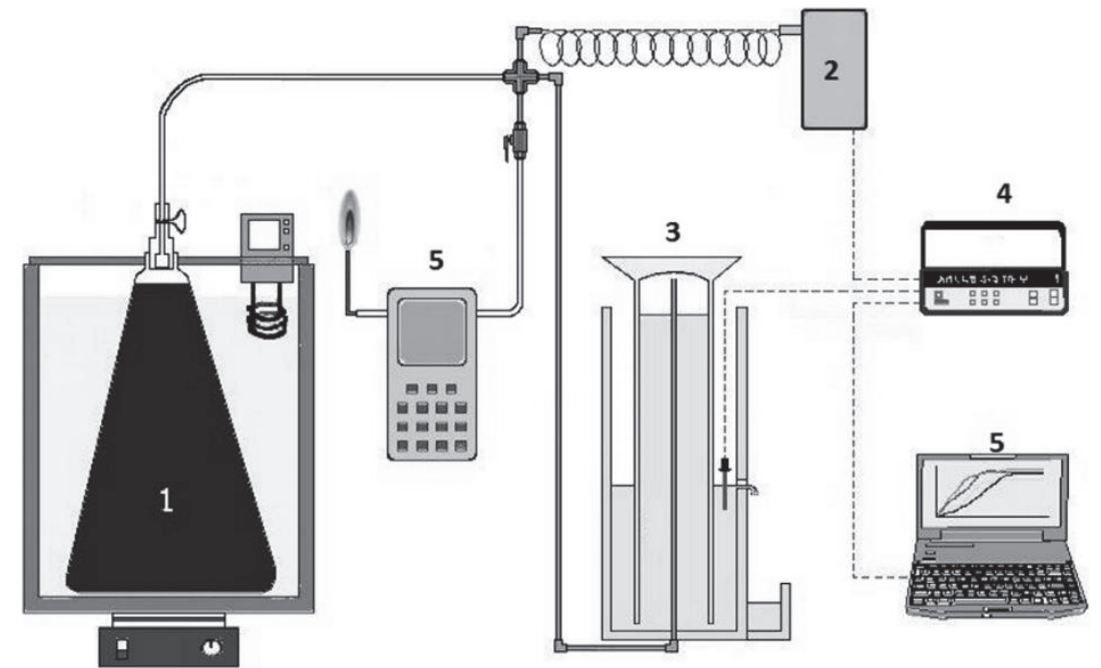

Fig. 1 - Experimental set-up: 1) anaerobic reactor; 2) pressure transducer; 3) gasometer; 4) data-logger; 5) personal computer; 6) gas analyzer

\section{Results and discussion}

\section{Specific methane production}

The specific methane production was determined experimentally by means of the aforementioned batch tests. The produced biogas was collected and analyzed obtaining the methane content that varied from $52.4 \%$ for BSG to $55.1 \%$ for BY (as reported in Table 4).

The practical SMP was estimated by plotting the final cumulative methane production versus the added load, as proposed by Raposo et al. (2006) ${ }^{33}$ : then the requested SMPvalues were obtained by the slopes of the straight lines, drawn in Figure 2 and reported in Table 4.

Brewer's spent grain revealed an average methane production of $0.284 \mathrm{~L} \mathrm{CH}_{4}$ (STP) $\mathrm{g}^{-1} \mathrm{COD}$ (expressing the substrate as COD) or $0.429 \mathrm{~L} \mathrm{CH}_{4}$ (STP) $\mathrm{g}^{-1}$ VS (expressing the substrate as VS), in agreement with data reported by Lorenz et al. $(2010)^{7}$ and by Bochmann et al. (2015) ${ }^{13}$. The average methane production of brewery yeast was of $0.255 \mathrm{~L} \mathrm{CH}_{4}$ (STP) $\mathrm{g}^{-1} \mathrm{COD}$, a value difficult to compare with literature data because previous studies considered the biomethanation of BY mixed with wastewater ${ }^{11,12}$.

The actual degree of conversion was calculated dividing the practical SMP values by the stoichiometric production of $0.350 \mathrm{~L} \mathrm{CH}_{4} \mathrm{~g}^{-1} \mathrm{COD}$ at STP conditions. According to Angelidaki and Sanders $(2004)^{18}$, degrees of conversion up to $90-95 \%$ can be achieved under favourable conditions (mainly water-soluble matter), whereas lower values of conversion, close to $30-60 \%$, are usual with highly particulate organic matter. As may be seen from
Table 4, good performance results were obtained with $\mathrm{AD}$ of the tested substrates. Lower degrees of conversion were reached with anaerobic digestion of exhausted brewery yeast. For this substrate, despite its great stoichiometric methane potential, the actual SMP proved to be low, probably due to its low $\mathrm{C} / \mathrm{N}$ and $\mathrm{COD} / \mathrm{N}$ ratios.

\section{Disintegration and hydrolysis phase}

The anaerobic digestion of a complex organic substrate is a non-linear bioprocess assumed to pass several stages, starting from complex organic material to monomers to gaseous compounds ${ }^{32}$. The extracellular breakdown of complex organic substrates to soluble substrates is expressed as disintegration and hydrolysis phase ${ }^{32}$. Due to the large fraction of organic matter that must be solubilized before its methanization, many studies have concluded that the disintegration/hydrolysis (solubilisation) phase is the rate-limiting step of the overall sewage sludge $\mathrm{AD}$ process $^{34}$.

Table 4 -Biomethanation tests results

\begin{tabular}{lcc}
\hline \multicolumn{1}{c|}{ Parameter } & BSG & BY \\
\hline Practical SMP [ $\left.\mathrm{L} \mathrm{CH}_{4} \mathrm{~g}^{-1} \mathrm{VS}\right]$ & 0.429 & - \\
{$\left[\mathrm{L} \mathrm{CH}_{4} \mathrm{~g}^{-1} \mathrm{COD}\right]$} & 0.284 & 0.255 \\
$\mathrm{CH}_{4}$ content [\%] & 52.4 & 55.1 \\
Actual degree of conversion [\%] & 81.1 & 72.9 \\
$\mathrm{SMP}_{\text {ult }}\left[\mathrm{L} \mathrm{CH}_{4} \mathrm{~g}^{-1} \mathrm{COD}\right]$ & 0.296 & 0.277 \\
& $( \pm 0.014)$ & $( \pm 0.014)$ \\
$k_{\text {sol }}\left[\mathrm{d}^{-1}\right]$ & 0.224 & 0.659 \\
& $( \pm 0.033)$ & $( \pm 0.059)$ \\
\hline
\end{tabular}



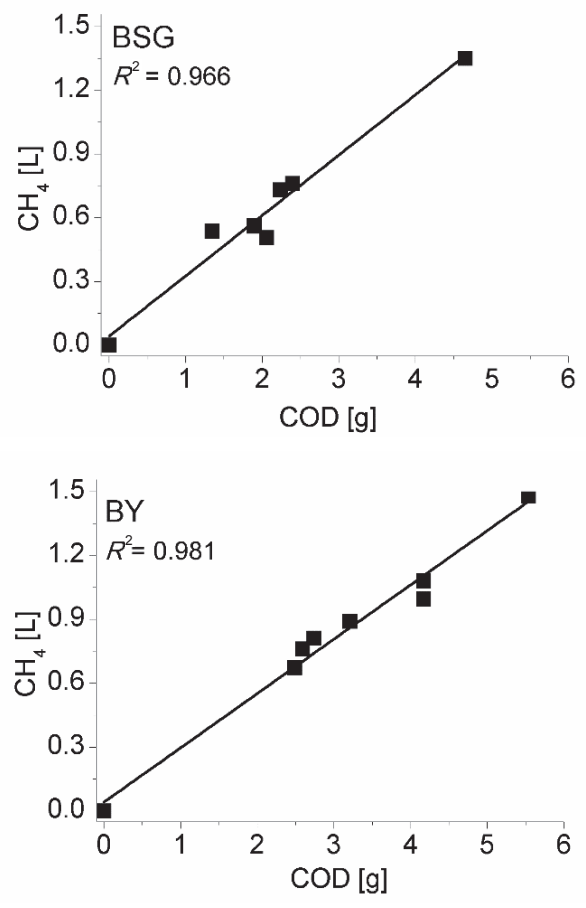

Fig. 2 - Average SMP estimation

Results from BMP tests can be employed to obtain information on the disintegration/hydrolysis rate $^{21}$. When there is no accumulation of intermediary products, the cumulative methane production can be represented by a first-order kinetic for the hydrolysis of particulate organic matter ${ }^{34-35}$ :

$$
\operatorname{SMP}_{(t)}=\operatorname{SMP}_{\text {ult }} \cdot\left(1-e^{\left(-k_{\mathrm{sol}} \cdot t\right)}\right)
$$

where $\mathrm{SMP}_{(t)}$ is the specific methane production $(\mathrm{L}$ $\left.\mathrm{CH}_{4} \mathrm{~g}^{-1} \mathrm{COD}\right)$ at time $t$ at standard conditions (STP), $\mathrm{SMP}_{\text {ult }}$ is the ultimate methane potential, and $k_{\text {sol }}$ is the solubilisation constant. The values of $\mathrm{SMP}_{\text {ult }}$ and $k_{\text {sol }}$ were evaluated using non-linear least squares curve fitting on the net cumulative specific methane production. This methodology usually employs the first part of the cumulative methane curve to estimate the solubilisation rate, so the $k_{\text {sol }}$ value could depend on the time used to estimate $i^{34}$. To check this point, Astals et al. $(2013)^{34}$ calculated the disintegration/hydrolysis rate for seven different sewage sludges using both the first part of the cumulative methane curve (following the previous methodology), and the entire curve (performing a regression analysis after linearising the eq. (5)): The authors found that no statistical difference was observed when the $k_{\mathrm{sol}}$ of the sludges was estimated by exponential custom or by linearization.

Figure 3 shows the fitting obtained for the two substrates. Estimated values of solubilisation rate constant are reported in Table 4 . The $k_{\text {sol }}$ values, ranging from $0.224 \mathrm{~d}^{-1}$ for brewer's spent grain to
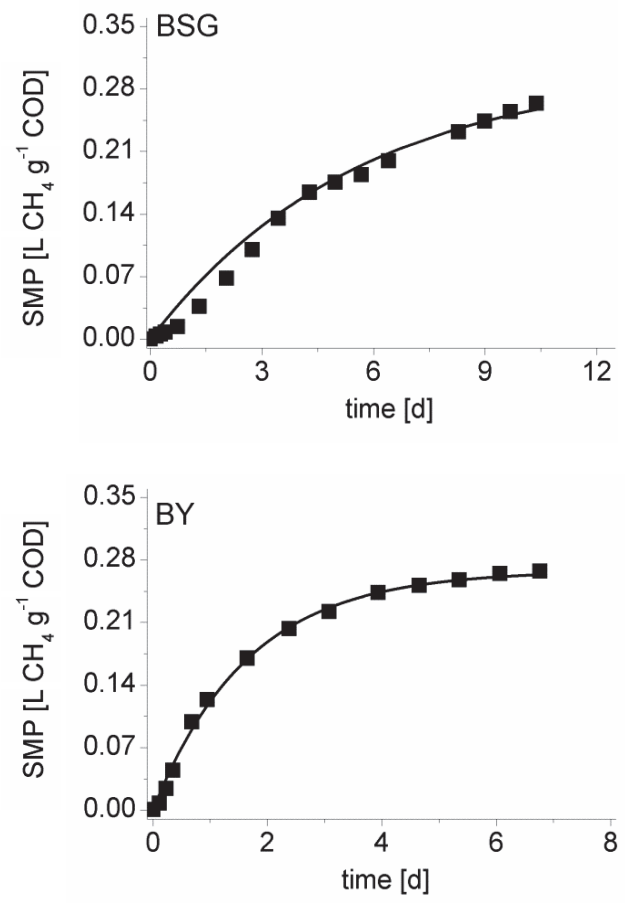

Fig. $3-\mathrm{SMP}\left(\mathrm{L} \mathrm{CH}_{4} \mathrm{~g}^{-1} \mathrm{COD}\right)$ profiles (* experimental; simulated)

$0.659 \mathrm{~d}^{-1}$ for brewery yeast, resulted in the same order of magnitude as those reported in literature ${ }^{35,37}$. It is worth noting that, although the final conversion degree of BY was not high, its solubilisation process occurs quickly, indicating that exhausted brewery yeast could be an efficient substrate for co-digestion purposes. For instance, blending the BY with a substrate with an optimal $\mathrm{C} / \mathrm{N}$ ratio and a low solubilisation rate (such as maize silage) could balance the substrates drawbacks improving the efficiency of the $\mathrm{AD}$ process.

\section{Conclusions}

The biomethanation potential of the two main solid waste fractions of beer production was evaluated. The approach applied aimed to compare the theoretical methane potential of the tested substrates (calculated according to experimental COD and elemental composition) with the practical SMP (obtained by BMP tests). The modelling approach was pragmatic, focusing only on the solubilisation step that was considered as limiting for the whole AD process.

The obtained SMP ranged from $0.255 \mathrm{~L} \mathrm{CH}_{4}$ $\mathrm{g}^{-1} \mathrm{COD}$ for exhausted brewery yeast to $0.284 \mathrm{~L}^{4}$ $\mathrm{CH}_{4} \mathrm{~g}^{-1} \mathrm{COD}$ for brewer's spent grain, achieving a high conversion degree. The estimated $k_{\text {sol }}$ values ranged from $0.224 \mathrm{~d}^{-1}$ for brewer's spent grain to $0.659 \mathrm{~d}^{-1}$ for brewery yeast. 


\section{List of symbols}

\begin{tabular}{l|c|l}
\hline Symbol & \multicolumn{1}{c|}{ Units } & \multicolumn{1}{c}{ Description } \\
\hline$B_{\text {0th, vs }} \quad \mathrm{L} \mathrm{CH}_{4} \mathrm{~g}^{-1} \mathrm{VS}$ & $\begin{array}{l}\text { Theoretical methane potential } \\
\text { related to volatile solids }\end{array}$ \\
$B_{\text {0th, COD }} \quad \mathrm{L} \mathrm{CH}_{4} \mathrm{~g}^{-1} \mathrm{COD}$ & $\begin{array}{l}\text { Theoretical methane potential } \\
\text { related to chemical oxygen demand }\end{array}$ \\
$\mathrm{SMP}_{\text {ult }}$ & $\mathrm{L} \mathrm{CH}_{4} \mathrm{~g}^{-1} \mathrm{COD}$ & Ultimate methane potential \\
$k_{\text {sol }}$ & $\mathrm{d}^{-1}$ & Solubilisation constant \\
\hline
\end{tabular}

\section{References}

1. Fillaudeau, L., Blanpain-Avet, P., Daufin, G., Water, wastewater and waste management in brewing industries, $\mathrm{J}$. Clean. Prod. 14 (2006) 463. doi: http://dx.doi.org/10.1016/j.jclepro.2005.01.002

2. TBOE 2014. http://www.brewersofeurope.org/uploads/mycms-files/documents/publications/2014/statistics_2014_ web 2.pdf (27.5.2014).

3. Ferreira, I. M. P. L. V. O., Pinho, O., Vieria, E., Tavarela, $J ., G$., Brewer's Saccharomyces yeast biomass: Characteristics and potential applications, Trends Food Sci. Tech. 21 (2010) 77 doi: http://dx.doi.org/10.1016/j.tifs.2009.10.008

4. Thomas, K. R., Rahman, P. K. S. M., Brewery wastes. Strategies for sustainability. A review, Asp. Appl. Biol. 80 (2006) 147.

5. Dos Santos - Mathias, T. R., Moretzsohn de Mello, P. P., Camporerese-Sérvulo, E. F., Solid wastes in brewing process: A review, J. Brew. Distilling. 5 (1) (2014).

6. Mussatto, S. I., Dragone, G., Roberto, I. C., Brewers'spent grain, generation, characteristics and potential applications, J. Cereal Sci. 43 (2006). doi: http://dx.doi.org/10.1016/j.jcs.2005.06.001

7. Lorenz, H., Fischer, P., Schumacher, B., Adler, P., Current EU-27 technical potential of organic waste streams for biogas and energy production, Waste Manage. 33 (2013) 2434. doi: http://dx.doi.org/10.1016/j.wasman.2013.06.018

8. Institute of Food Research, Repro Final Science Report FOOD-CT-2005-006922 REPRO, Reducing Food Processing Waste, http://cordis.europa.eu/docs/publications/1266/126625891-6_en.pdf, (24.05.2016).

9. Aliyu, S., Bala, M., Brewer's spent grain: A review of its potentials and applications, Afr. J. Biotechnol. 10 (3) (2011) 324.

10. Pires, E. J., Ruiz, H. A., Teixeira J. A., Vicente, A. A., A new approach on brewer's spent grains treatment and potential use as lignocellulosic yeast cells carriers, J. Agric. Food Chem. 60 (2012) 5994. doi: http://dx.doi.org/10.1021/jf300299m

11. Neira, K., Jeison, D., Anaerobic co-digestion of surplus yeast and wastewater to increase energy recovery in breweries, Water Sci. Technol. 61 (5) (2010) 1129. doi: http://dx.doi.org/10.2166/wst.2010.052

12. Zupančič, G., Škrjanec, I., Logar, R. M., Anaerobic co-digestion of excess brewery yeast in a granular biomass reactor to enhance the production of biomethane, Biores. Technol. 124 (2012) 328. doi: http://dx.doi.org/10.1016/j.biortech.2012.08.064

13. Bochmann, G., Drosg, B., Fuchs, W., Erratum: Anaerobic digestion of thermal pretreated brewers' spent grains, Environ. Prog. Sustain. Energy 34 (6) (2015) 1832. doi: http://dx.doi.org/10.1002/ep.12266

14. Colussi, I., Cortesi, A., Gallo, V., Vitanza, R., Biomethanization of brewer's spent grain evaluated by application of the Anaerobic Digestion Model No.1, Environ. Prog. Sustain. Energy, Advance online publication. doi: http://dx.doi.org/10.1002/ep.12326

15. Derbal, K., Bencheick-lehocine, M., Cecchi, F., Meniai, A. H., Pavan, P., Application of the IWA ADM1 model to simulate anaerobic co-digestion of organic waste with waste activated sludge in mesophilic condition, Biores. Technol. 100 (2009) 1539.

doi: http://dx.doi.org/10.1016/j.biortech.2008.07.064

16. Imamović, N., Goletić, Š., Testing the biomethane yield of degradable wastes of meat industry by BMP test, Chem. Biochem. Eng. Q. 28 (1) (2014) 153.

17. Garcia-Gen, S., Rodríguez, J., Lema, J. M., Optimisation of substrate blends in anaerobic co-digestion using adaptive linear programming, Bioresour. Technol. 173 (2014) 159. doi: http://dx.doi.org/10.1016/j.biortech.2014.09.089

18. Angelidaki, I., Sanders, W., Assessment of the anaerobic biodegradability of macropollutants, Rev. Environ. Sci. Biotechnol. 3 (2) (2004) 117. doi: http://dx.doi.org/10.1007/s11157-004-2502-3

19. Nieto, P. P., Hidalgo, D., Irusta, R., Kraut, D., Biochemical methane potential (BMP) of agro-food wastes from the Cider Region (Spain), Water Sci. Technol. 66 (9) (2012) 1842. doi: http://dx.doi.org/10.2166/wst.2012.372

20. Wang, X., Yang, G., Li, F., Feng, Y., Ren, G., Han, X., Evaluation of two statistical methods for optimizing the feeding composition in anaerobic co-digestion: Mixture design and central composite design, Bioresour. Technol. 131 (2013) 172 .

doi: http://dx.doi.org/10.1016/j.biortech.2012.12.174

21. Angelidaki, I., Alves, M., Bolzonella, D., Borzacconi, L., Campos, L., Guwy, A., Kalyauzhnyi, S., Jenicek, P., van Lier, J. B., Defining the biomethane potential (BMP) of solid organic wastes and energy crops: a proposed protocol for batch assays, Water Sci. Technol. 59 (2009) 927. doi: http://dx.doi.org/10.2166/wst.2009.040

22. Garcia-Gen, S., Sousbie, P., Rangaraj, G., Lema, J. M., Rodriguez, J., Steyer, J. P. Michel Torrijos, M., Kinetic modelling of anaerobic hydrolysis of solid wastes, including disintegration processes, Waste Manage. 35 (2015) 96. doi: http://dx.doi.org/10.1016/j.wasman.2014.10.012

23. Álvarez, J. A., Otero, L., Lema, J. M., A methodology for optimizing feed composition for anaerobic co-digestion of agro-industrial wastes, Bioresour. Technol. 101 (2010) 1153.

doi: http://dx.doi.org/10.1016/j.biortech.2009.09.061

24. APHA, AWWA, WPCF, Standard methods for the examination, of water and wastewater. $17^{\text {th }}$ ed. Washington, DC, (2005).

25. Raposo, F., de la Rubia, M. A., Borja, R., Alaiz, M., Assessment of a modified and optimised method for determining chemical oxygen demand of solid substrates and solutions with high suspended solid content, Talanta 76 (2008) 448. doi: http://dx.doi.org/10.1016/j.talanta.2008.03.030

26. Kanauchi, O., Mitsuyama, K., Araki, Y., Development of a functional germinated barley foodstuff from brewer's spent grain for the treatment of ulcerative colitis, J. Am. Soc. Brew. Chem. 59 (2001) 59.

27. Pacheco, M. T. B., Caballero-Córdoba, G. M., Sgarbieri, V. $C$., Composition and nutritive value of yeast biomass and yeast protein concentrates, J. Nutr. Sci. Vitaminol. 43 (6) (1997) 601. doi: http://dx.doi.org/10.3177/jnsv.43.601 
28. Koch, K., Lübken, M., Gehring, T., Wichern, M., Horn, H., Biogas from grass silage - Measurements and modeling with ADM1, Bioresour. Technol. 101 (2010) 8158. doi: http://dx.doi.org/10.1016/j.biortech.2010.06.009

29. Buswell, A. M., Neave, S. L., Laboratory studies of sludge digestion. Illinois Division of State Water Survey, Bulletin No. 30 (1930).

30. Mottet, A., François, E., Latrille, E., Steyer, J. P., Déléris, S., Vedrenne, F., Carrère, H., Estimating anaerobic biodegradability indicators for waste activated sludge, Chem. Eng. J. 160 (2010) 488 doi: http://dx.doi.org/10.1016/j.cej.2010.03.059

31. Colussi, I., Cortesi, A., Gallo, V., Rubesa Fernandez, A. S., Vitanza, R., Methane production from solid potatoes by a procedure simulating a bench-scale sequencing batch reactor anaerobic process, Chem. Biochem. Eng. Q. 28 (1) (2014) 119.

32. Biernacki, P., Steinigeweg, S., Borchert, A., Uhlenhut, F., Application of Anaerobic Digestion Model No. 1 for describing anaerobic digestion of grass, maize, green weed silage, and industrial glycerine, Bioresour. Technol. 127 (2013) 188

doi: http://dx.doi.org/10.1016/j.biortech.2012.09.128
33. Raposo, F., Banks, C. J., Siegert, I., Heaven, S., Borja, R., Influence of inoculum to substrate ratio on the biochemical methane potential of maize in batch tests, Process Biochem. 41 (2006) 1444.

doi: http://dx.doi.org/10.1016/j.procbio.2006.01.012

34. Astals, S., Esteban-Gutierrez, M., Fernández-Arévalo, Aymerich, E., Garcia-Heras, J. L., Mata-Alvarez, J., Anaerobic digestion of seven different sewage sludges: A biodegradability and modelling study, Water Res. 47 (2013) 6033.

doi: http://dx.doi.org/10.1016/j.watres.2013.07.019

35. Veeken, A., Hamelers, B., Effect of temperature on hydrolysis rates of selected biowaste components, Bioresour. Technol. 69 (3) (1999) 249. doi: http://dx.doi.org/10.1016/S0960-8524(98)00188-6

36. Gali, A., Benabdallah, T., Astals, S., Mata-Alvarez, J., Modified version of ADM1 model for agro-waste application, Bioresour. Technol. 100 (2009) 2783. doi: http://dx.doi.org/10.1016/j.biortech.2008.12.052

37. Vavilin, V. A., Fernandez, B., Palatsi, J., Flotats, X., Hydrolysis kinetics in anaerobic degradation of particulate organic material: An overview, Waste Manage. 28 (6) (2008) 939.

doi: http://dx.doi.org/10.1016/j.wasman.2007.03.028 